\title{
BERNALAR DAN ARGUMENTASI MELALUI PROBLEM BASED LEARNING
}

\author{
Giena Sri Restu Kumala ${ }^{1)}$, Ilah Nurlaelah ${ }^{2)}$, Ina Setiawati ${ }^{3)}$ \\ ${ }^{1}$ Program Studi Pendidikan Biologi FKIP, Universitas Kuningan \\ Email: gienasrirestukumala@gmail.com \\ ${ }^{2}$ Program Studi Pendidikan Biologi FKIP, Universitas Kuningan \\ Email: ilah.nurlaelah@uniku.ac.id \\ ${ }^{3}$ Program Studi Pendidikan Biologi FKIP, Universitas Kuningan \\ Email: ina.setiawati@uniku.ac.id
}

APA Citation: Kumala, G.S.R., Nurlaelah, I., \& Setiawati, I. (2017). Bernalar Dan Argumentasi Melalui Problem Based Learning. Quagga: Jurnal Pendidikan dan Biologi, 9(2), 12-17. doi: 10.25134/quagga.v9i02.739.

\begin{abstract}
Abstrak: Metode penelitian yang digunakan adalah Eksperimental Design. Pengambilan sampel dilakukan dengan menggunakan teknik Cluster Random Sampling. Uji hipotesis dengan menggunakan uji Manova. Hasilpenelitianinimenjelaskanterdapatkorelasi antara bernalar dan argumentasi siswa yang terjadi karena faktor internal dan faktor eksternal, selainituitu, strategi pembelajaran dan tingkat kognitif siswa dalam memandang sebuah permasalahan dapat mempengaruhi pola penalaran siswa tersebut. Strategipembelajaranproblem based learningmemfasilitasisiswa untukdikenalkandenganmasalah yang bersifatill-structured yang dapatmelatihsiswadalammembuat solusi untuk memecahkan permasalahan.
\end{abstract}

Kata Kunci: Problem Based Learning, Bernalar, Argumentasi

Abstract: The research method used is Experimental Design. Sampling is done using Cluster Random Sampling techniques.Hypothesis testing using Manova test.The learning strategy and cognitive The reason for this is that there is a correlation between reasoning and student argumentation that occurs due to internal factors and external factors..Problem based learning strategies facilitate students to be introduced to ill-structured problems that can train students to create solutions to solve problems.

Keywords: Problem Based Learning, Reasoning, Argumentation

\section{PENDAHULUAN}

Fenomena saat ini siswa masih menganggap bahwa mata pelajaran Biologi merupakan mata pelajaran yang bersifat hafalan bukan kepemahaman ataupun penalaran. Penelitian PISA (2009, dalam Putri, 2014) menyatakan bahwa siswa belum mampu menggali kemampuan penalaran, karena di sekolahsekolah belum mengoptimalkan proses pembelajaran yang berbasis sains. Penalaran akan digunakan siswa untuk mengatasi masalah yang sedang dihadapinya, namun setiap siswa memiliki cara yang berbeda dalam mengatasi permasalahan tersebut sesuai dengan hasil penalaran masing-masing. Perbedaan solusi yang ditawarkan dapat memungkinkan terjadi suatu persedatan tentang masalah yang sama. Dalam keadaan demikian maka siswa akan berargumentasi sesuai dengan hasil penalaran mereka, bahkan mempertahankan hingga dapat mempengaruhi orang lain untuk menerima pendapatnya (Keraf Gorys, 2010:115).
Berdasarkan pengalaman Program Praktek Lapangan (PPL) siswa cenderung pasif dan pada saat guru memberikan kesempatan siswa untuk bertanya atau memberikan pendapatnya, hanya beberapa orang saja yang mampu mengemukakan pendapatnya. Sebelumnya pernah ada yang meneliti tentang argument dan menyatakan hasil penelitian bahwa rata-rata argumentasi siswa SMA berada pada level 2 yang menunjukkan bahwa argumentasi berisi claim, dengan salah satu the ground, warrant, atau backing. Astuti, Tiwi (2014:104). Namun belum ada penelitian yang mencari hubungan Argumen dengan Bernalar setelah siswa dibiasakan pembelajaran model problem based learning.

Keterampilan argumentasi secara langsung atau tidak langsung akan terintegrasi pada setiap kegiatan belajar mengajar yang dialami siswa untuk mendapatkan pengetahuan baru. Pengetahuan baru akan diterima siswa, namun sebelumnya akan melalui proses internalisasi dalam diri siswa yang memaksa siswa untuk 
Quagga: Jurnal Pendidikan dan Biologi

Volume 9, Nomor 2, Juli 2017

menalar mengenai konsep tersebut dan berusaha mencari kebenaran. Untuk dapat mengkondisikan siswa supaya dapat belajar menalar dan mengemukakan pendapat (berargumentasi), maka akan lebih efektif apabila siswa dihadapkan pada masalah-masalah yang perlu mendapat pemecahan, sehingga memungkinkan terjadinya proses menalar dan berargumen pada diri siswa untuk mendapatkan pemecahan masalah tersebut. Masalah yang diberikan kepada siswa dikemas dalam bentuk kasus-kasus yang saling terkait satu sama lain, sehingga dapat membantu siswa untuk memahami pokok-pokok permasalahan yang terkandung. Model pembelajaran yang sesuai dengan kondisi diatas adalah model pembelajaran berbasis masalah.

\section{METODOLOGI PENELITIAN}

Metode penelitian yang digunakan dalam penelitian ini adalah metode eksperimental. Adapun bentuk desain yang digunakan dalam penelitian ini adalah posttest-only control group design. Variabel bebas pada penelitian ini adalah model PBL, dan variable terikatya itu kemampuan bernalar dan keterampilan argumentasi. Penelitian ini untuk menganalisis penerapan model pembelajaran PBL (Problem Based Learning) terhadap kemampuan bernalar dan keterampilan argumentasi dan hubungan antara kemampuan bernalar dan keterampilan argumentasi. Pada penelitian ini teknis analisis data menggunakan uji Manova (Multivariate Analysis of Variance) dan uji korelasi Product Moment dengan bantuan software SPSS versi 21.

\section{HASIL DAN PEMBAHASAN}

Hasil analisis kemampuan bernalar siswa, terdapat pada gambar 1 mengenai perbedaan rata-rata hasil posttest untuk setiap indikator. Pada kelas yang menerapkan model PBL (Problem Based Learning) skor tertinggi kemampuan bernalar yaitu indikator menganalisis perspektif sebesar 3,34. Begitupula pada kelas yang menerapkan metode diskusi dengan skor tertinggi kemampuan bernalar yaitu indikator menganalisis perspektif sebesar 3,13.
p-ISSN 1907-3089, e-ISSN 2651-5869

https://journal.uniku.ac.id/index.php/quagga

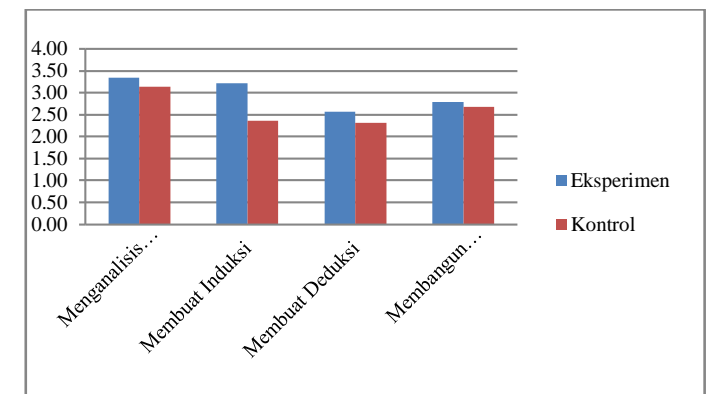

Gambar 1. Hasil Posttest Kemampuan Bernalar Siswa pada Setiap Indikator

Persentase untuk masing-masing level kemampuan bernalar siswa tersaji pada gambar 2.1 berikut ini:

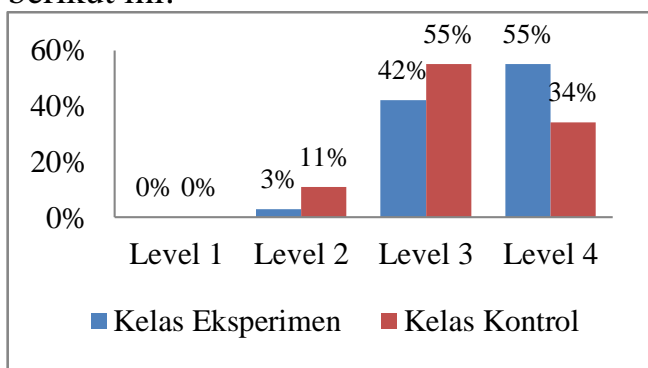

Gambar 2. Persentase Jumlah Siswa pada Setiap Level Kemampuan Bernalar Siswa Kelas Eksperimen dan Kelas Kontrol

Tabel 1. Uji Hipotesis Data

\begin{tabular}{|c|c|c|}
\hline Variabel & Sig. & Kesimpulan \\
\hline Bernal ar & 0,012 & $\begin{array}{l}\mathrm{p}<0,05 \\
\text { tolak Ho }\end{array}$ \\
\hline Argumentasi & 0,017 & $\begin{array}{l}\mathrm{p}<0,05, \\
\text { tolak Ho }\end{array}$ \\
\hline $\begin{array}{l}\text { Korelasi } \\
\text { bernalar dengan } \\
\text { argumentasi }\end{array}$ & 0,046 & $\begin{array}{l}\mathrm{p}<0,05, \\
\text { tolak Ho }\end{array}$ \\
\hline
\end{tabular}

Berdasarkan hasil uji manova diperoleh bahwa terdapat pengaruh penerapan model pembelajaran PBL terhadap kemampuan bernalar siswa. Plotnik (2006 dalam Remigio dkk, 2014) mendefinisikan bernalar sebagai proses mental yang melibatkan dan menerapkan pengetahuan untuk memecahkan masalah, membuat keputusan, dan mencapai tujuan. Hal tersebut dapat didukung dengan penerapan model pembelajaran PBL. Pembelajaran PBL mengharuskan siswa untuk melakukan investigasi autentik yang berusaha menemukan solusi riil untuk masalah riil, dimana siswa harus menganalisis dan menetapkan suatu masalah, dan membuat solusi-solusi alternative dan menentukan pilihan solusi terbaik serta mengevaluasi solusi dan fakta atau teori yang 
bekerja didalam kelompok-kelompok kecil. Sehingga siswa pada kelas eksperimen dituntut untuk mengembangkan keterampilan berpikir, menyelesaikan masalah, dan bernalar ketika proses pembelajaran.

Pelaksanaan model PBL melalui sintaknya dapat melatih komponen-komponen bernalarnya, terutama pada fase investigasi kelompok, siswa akan belajar dalam hal membangun dukungan dan menganalisis perspektif. Sementara pada fase mengembangkan dan menyajikan hasil siswa akan belajar membuat induksi dan deduksi, untuk fase menganalisis masalah dan mengevaluasi hasil pemecahan masalah, siswa akan belajar membuat deduksi dan membuat induksi (Komala, 2015:84).

Herman (2007) menjelaskan bahwa penerapan model PBL dapat meningkatkan kemampuan bernalar siswa. Menurut Herman (2007) bahwa bahan ajar yang dapat meningkatkanbernalarsiswa adalah bahan ajar yang menyajikan permasalahan dalam kehidupan nyata. Di samping itu, model PBL memiliki ciri dapat membantu siswa untuk mengembangkan pengetahuan barunya dan bertanggung jawab dalam pembelajaran yang mereka lakukan sehingga dapat mengembangkan kemampuan bernalarsiswa. Menurut teori perkembangan kognitif Piaget dalam Putri (2014), siswa SMA telah memasuki tahap perkembangan kognitif tahapan operasional formal. Pada tahap ini siswa telah dapat berpikir secara abstrak, menalar logis, dan menarik kesimpulan dari informasi yang tersedia. Teori ini sesuai dengan siswa kelas X IPA yang memiliki kemampuan bernalar yang baik yaitu kemampuan membuat deduksi untuk menarik kesimpulan, membuat dukungan dengan bernalar. Magsino (2014) mengatakan penerapan PBL mampu secara efektif mengembangkan kemampuan berpikir tingkat tinggi salah satunya bernalar, selain itu siswa mampu secara efektif membandingkan dan mengkritik hasil kelompok mereka dengan kelompok lain ketika melakukan kegiatan diskusi. Hal ini didukung oleh Koray dan Abdullah Koray (2013) bahwa siswa yang berada pada kelas PBL memiliki nilai kemampuan bernalar dengan rata-rata yang lebih baik daripada siswa dikelas yang tidak menerapkan PBL.

Adapun persentase untuk setiap level kualitas argumentasi siswa tersaji pada gambar 3 dan 4 berikut ini :

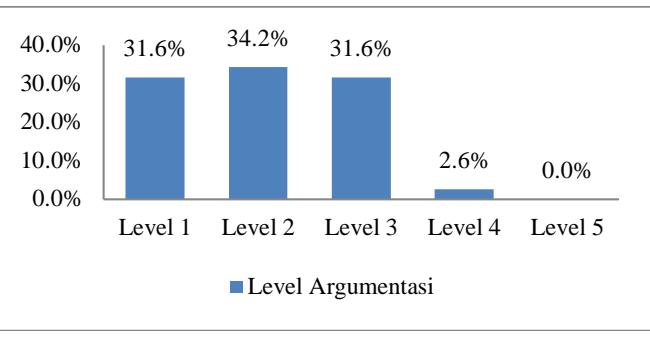

Gambar 3.Persentase Jumlah Siswa pada Setiap Level Kualitas Argumentasi Kelas Eksperimen

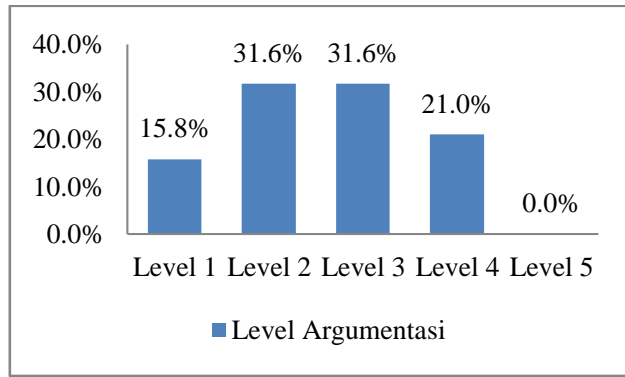

Gambar 4. Persentase Jumlah Siswa pada Setiap Level Kualitas Argumentasi Kelas control

Berdasarkan gambar 3 dan gambar 4 terlihat bahwa pada kelas eksperimen kualitas argumentasi siswa merata pada level 1, level 2 dan level 3. Sedangkan, pada kelas kontrol kualitas argumentasi siswa merata pada level 2 dan 3. Berdasarkan hasil uji manova diperoleh bahwa terdapat pengaruh penerapan model PBL (Problem Based Learning) terhadap keterampilan argumentasi siswa pada kelas eksperimen. Pembelajaran dengan menggunakan model PBL (Problem Based Learning) sangat efektif untuk melatih keterampilan argumentasi sains siswa karena pada saat proses pembelajaran siswa dilatih untuk dapat memecahkan permasalahan yang diberikan guru dalam proses diskusi, dimana siswa dihadapkan pada permasalahan yang ill-structure untuk membimbing proses pembelajaran dan memerlukan beberapa solusi yang berbeda dengan demikian akan menghasilkan perbedaan dari hasil diskusi dan meminta siswa untuk berargumentasi sesuai dengan hasil diskusi kelompoknya (Chin, Christine et al, 2005).

Penerapan model PBL pada pembelajaran, siswa akan tertantang dalam belajarnya karena siswa dihadapkan pada permasalahan yang terjadi pada kehidupan sehari-hari. Sesuai dengan pendapat Nurhadi \& Senduk (dalam Hutama, 2014) yang menyatakan siswa akan belajar dengan baik dan termotivasi apabila yang mereka pelajari berkaitan dengan kehidupan sehari-hari, serta proses belajar akan produktif jika siswa terlibat aktif dalam proses belajar. 
Dengan menggunakan model pembelajaran PBL guru memberikan kesempatan pada siswa untuk belajar memahami suatu materi yang dipelajarinya dari permasalahan yang disajikan. Melalui pemberian permasalahan, siswa dirangsang untuk memberikan suatu solusi untuk memecahkan permasalahan tersebut, sehingga dalam proses memecahkan masalah tersebut siswa harus berdiskusi dan berkomunikasi dengan kelompoknya untuk bertukar pendapat (berargumentasi) mengenai masalah yang disajikan yang berkaitan dengan kehidupan sehari-hari. Pembelajaran melalui masalah seperti Problem Based Learning (PBL) ternyata dapat menstimulasi keterampilan argumentasi siswa. Tahapan model PBL juga bersifat student centered menjadikan siswa lebih aktif dalam mengemukakan argumentasinya. Guru dapat membimbing dan mengarahkan diskusi terutama diarahkan untuk meningkatkan penalaran secara kolaboratif. Permasalahan PBL yang bersifat Konflik kognitif dapat dimanfaatkan untuk menstimulasi argumentasi siswa (Setiawati, 2017).

Hasil uji hipotesis menunjukan bahwa terdapat berhubungan yang signifikan antara kemampuan bernalar dengan keterampilan argumentasi, dengan keeratan hubungan yang rendah yaitu sebesar 0,325 . Hubungan antara kemampuan bernalar dan keterampilan argumentasi bersifat liner dan positif. Hal tersebut didukung oleh Warnick \& Inch (dalam Dawud, 2008) yang mengatakan bahwa bernalar terletak sebagai salah satu unsur argumentasi. Selain itu, Azmi (2013) mengemukakan bahwa penalaran juga merupakan aktivitas berpikir yang abstrak. Untuk mewujudkannya diperlukan simbol. Simbol atau lambang yang digunakan dalam penalaran berbentuk bahasa, sehingga wujud penalaran akan berupa argumen. Dari beberapa pendapat yang telah disampaikan, dapat disimpulkan bahwa penalaran ini merupakan bagian utama untuk seseorang dapat berargumentasi.

Keeratan bernalar dan argumentasi siswa terjadi karena beberapa faktor, diantaranya yaitu faktor internal dan faktor eksternal. Hal serupa disampaikan oleh Widanti,dkk (2012) yang mengemukakan bahwa bernalar dipengaruhi oleh faktor internal dan faktor eksternal. Faktor internal adalah faktor yang berasal dari dalam diri siswa sendiri seperti tingkat kecerdasan, sikap, minat, bakat dan kemauan serta motivasi diri dalam belajar. Sementara Faktor eksternal (faktor dari luar siswa) yakni kondisi lingkungan di sekitar siswa, seperti proses pembelajaran, model atau metode yang digunakan, alat dan bahan pembelajaran. Disamping itu,strategi pembelajaran, kemampuan diri sendiri, sikap siswa dan tingkat kognitif siswa dalam memandang sebuah permasalahan dapat mempengaruhi pola penalaran siswa tersebut. Perkembangan kognitif siswa dapat mempengaruhi kemampuan bernalarnya. Sejalan dengan Rustaman (2005, dalam Susanti, 2013) yang mengatakan bahwa kognitif berhubungan dengan pengembangan kemampuan otak dan penalaran peserta didik. Psikomotor berhubungan dengan cara pesertadidik pada waktu mengembangkan hasil belajar.

Dari beberapa faktor yang telah disampaikan faktor lain yang menghambat untuk berargumentasi adalah kemampuan intelegensi siswa. Menurut Sobur, Alex (2003:245) menyatakan bahwa setiap orang memiliki kemampuan intelegensi yang berbeda satu sama lain. Ada yang memiliki kemampuan intelegensi tinggi dan rendah sehingga akan mempengaruhi dirinya untuk menanggapi dan merespon suatu pernyataan. Selain itu adanya pembatasan diri seperti yang dikemukakan oleh Wade \& Carole Tavris (2008:303) bahwa orang yang berbeda pendapat memutuskan untuk tetap tidak berbicara daripada membuat permasalahan, melukai perasaan teman dan mempermalukan diri sendiri. Hal tersebut tercermin pada kelas eksperimen yang kebanyakan berdiam diri saat temannya berargumen atau memberi pernyataan yang bertentangan.

\section{SIMPULAN}

Melalui pemberian permasalahan, siswa dirangsang untuk memberikan suatu solusi untuk memecahkan permasalahan, sehingga dalam proses memecahkan masalah tersebut siswa harus berdiskusi dan berkomunikasi dengan kelompoknya untuk bertukar pendapat (berargumentasi) mengenai masalah yang disajikan yang berkaitan dengan kehidupan sehari-hari. Pembelajaran melalui masalah seperti Problem Based Learning (PBL) ternyata dapat menstimulasi keterampilan argumentasi siswa. Tahapan model PBL juga bersifat student centered menjadikan siswa lebih aktif dalam mengemukakan argumentasinya.

\section{REFERENSI}

Astuti, Tiwi Puji. 2014. Penerapan Model Pembelajaran Problem Based Learning Berbasis Kerangka Instruksional 
Quagga: Jurnal Pendidikan dan Biologi

Volume 9, Nomor 2, Juli 2017

Marzano terhadap Kualitas Argumentasi Siswa Pada Konsep Animalia di Kelas X SMA Negeri 2 Kuningan. Skripsi FKIP UNIKU : Tidak diterbitkan

Azmi, Ulul. 2013. Profil Kemampuan Penalaran Matematika dalam Menyelesaikan Masalah Matematika Ditinjau dari Kemampuan Matematika Pada Materi Persamaan Garis Lurus Kelas VIII SMP YPM 4 Bohar Sidoarjo. [Online]. Undergraduate Thesis. Tersedia : digilib.uinsby.azc.id. Diakses pada tanggal 24 April 2016

Bilgin Ibrahim, Erdal Senocak dan Mustafa Sozbilir. 2009. The Effects of ProblemBased Learning Instruction on University Students; Performance of Conceptual an Quantitive Problems in Gas Concepts. [Online]. Eurasia Journal of Mathematics, Science and Technology Education. Tersedia http://ejmste.com.Eurasia_v5n2 Bilgin_etal. Diakses 28 Februari 2016

Chin, Christine dan Li-Gek Chia. 2005. Problem Based Learning: Using ill-Structured Problems in Biology Project. [Online]. Wiley Periodicals. Tersedia : www.interscience.wiley.com. Diakses pada tanggal 10 Mei 2016

Dawud. 2008. Penalaran dalam Karya Tulis Populer Argumentatif. [Online]. Jurnal Bahasa dan Seni. Tersedia : http://sastra.um.ac.id/wp-content/ uploads/09/10/Penalaran-dalam-KaryaTulis-PopulerArgumen-Dawud.pdf. Diakses pada tanggal 17 Januari 2016

Fischer, Frank, et al. 2014. Science Reasoning and Argumentation: Advancing an Interdisciplinary Research Agenda in Education. [Online]. Education Research Review. Tersedia http://journals.sfu.ca/flr/index.php/journ al/ article/view/96. Diakses pada tanggal 21 Mei 2016

Herman, Tatang. 2007. Pembelajaran Berbasis Masalah Untuk Meningkatkan Kemampuan Penalaran Matematis Siswa SMP. [Online]. Jurnal Cakrawala Pendidikan: Februari 2007, Th. XXXVI. No. $\quad 1 . \quad$ Tersedia :http://eprints.uny.ac.id/398/1/pembelaja ran_berbasis_masalah.pdf. Diakses tanggal 23 Mei 2015.

Setiawati, Ina dan Nurlaelah, Ilah. 2017. AnalisisProfilKemampuanBerargumenta
p-ISSN 1907-3089, e-ISSN 2651-5869

https://journal.uniku.ac.id/index.php/quagga

si Guru Dan Mahasiswa Calon Guru Dalam Pembelajaran Biologi Menggunakan Model Toulmin Argumen Pattern (TAP) Dan Upaya Perbaikannya. [Online]. Jurnal Quagga vol 9 No.1 Januari 2017, Tersedia :https://journal.uniku.ac.id/index.php/qua $\mathrm{gga/article/view/512}$

Hutama, Fajar Surya. 2014. Pengaruh Model PBL melalui Pendekatan CTL terhadap HasilBelajar IPS. [Online]. Jurnal Pendidikan Humaniora. Tersedia : http://journal.um.ac.id/index. Diakses pada tanggal 8 Mei 2016

Keraf, Gorys. 2010. Argumentasi dan Narasi. Jakarta : Nusa Indah.

Koray, Ozlem dan Abdullah Koray. 2013. The Effectiveness of Problem-Based Learning Supported with computer simulations on reasoning Ability. [Online]. Procedia-Social and Behavioral Sciences, Volume 106 (2013). Tersedia : http://www.sciencedirect.com/science/art icle/pii/S187704281304. Diakses pada tanggal 21 Mei 2016

Magsino, M. Richard. 2014. Enhancing Higher Order Thinking Skills in a Marine Biology Class through Problem-Based Learning.[Online]. Asia Pasific Journal of Multidisciplinary Reasearch. P-ISSN 2350-7756, Volume 2 No.5 E-ISSN 23508442. Tersedia :www.apjmr.com. Diakses pada tanggal 22 Mei 2016

Martyanti, Adhetia. 2013. Membangung SelfConfidence dalam Pembelajaran Matematika dengan Pendekatan Problem Solving. [Online]. Prosiding : Seminar Nasional Pendidikan Matematika dan Pendidikan Matematika. Tersedia : https://core.ac.uk/download/pdf/1845426 3.pdf. Diakses pada tanggal 18 Mei 2016

Okumus, Seda \& Suat Unal. 2012. The Effect Model on Students' Achievement and Argumentation Skills in Science. [Online]. Procedia: Social and Behavior Science. Tersedia www.sciencedirect.com. Diakses pada tanggal 20 Mei 2016

Putri, Ayu Eka. 2014. Kemampuan Penalaran Siswa Kelas X IPA SMA Terkait Dengan Konsep Biologi. [Online]. Prosiding Mathematics and Sciences Forum 2014 ISBN 978-602-0960-00-5. 
Quagga: Jurnal Pendidikan dan Biologi

Volume 9, Nomor 2, Juli 2017

Tersedia : $\quad$ http://prosiding. upgrismg.ac.id. Diakses 10 Januari 2016.

Remigio, Krisette, Rosanelia T. Yangco \& Allen

A. Espinosa. 2014. Analogy-Enhanced Instruction: Effects on Reasoning Skills in Science. [Online]. The Malaysian Journal of Educational Science, Volume 2, Issue 2. Tersedia : http://eric.ed.gov/?id=EJ1086234.

Diakses pada tanggal 21 Mei 2016

Santoso, Tri dan Supriadi. 2014. Pembelajaran Penalaran Argumen Berbasis Peta Konsep Untuk Meningkatkan Pemahaman Konsep Kimia. [Online]. Prosiding Seminar Nasional Kimia Universitas Negeri Surabaya. Tersedia: http://ccs.infospace.com/ClickHandler.as $h x ? l d=20160218 . p d f$. Diakses pada tanggal 23 Januari 2016

Sobur, Alex. 2003. Psikologi Umum. Bandung : Pustaka Setia

Sudrajat, Akhmad. 2011. Pembelajaran Berdasarkan Masalah-Problem Based Learning. [Online]. Tersedia : http://Akhmadsudrajat.wordpress.com/ 2011/09/28/pembelajaran-berdasarkanmasalah/. Diakses pada tanggal 20 Februari 2016

Susanti, Rahmi. 2013. Pengaruh Penerapan Pembelajaran Berbasis Masalah pada Praktikum Fotosintesis dan Respirasi untuk Meningkatkan Kemampuan Generik Sains Mahasiswa Pendidikan Biologi FKIP Unsri. [Online]. Seminar Kenaikan Jabatan Lektor Pada Fakultas-FKIP Unsri O8 Mei 2013. Tersedia http://eprints.unsri.ac.id/3247/1/Makala h_Seminar_Kenaikan_Jabatan.pdf. Diakses pada tanggal 25 Mei 2016

Undang-Undang SISDIKNAS. 2003. UndangUndang No.20 tahun 2003 tentang Sistem Pendidikan Nasional. Lembaran Negara RI Tahun 2003, No. 60. Sekretariat Negara. Jakarta.

Wade, Carole dan Carole Tavris. 2008. Psikologi. Edisi ke 9. Diterjemahkan oleh: Benedict Widyasinta \& Darma Juwono. Jakarta : Gelora Aksara Pratama
p-ISSN 1907-3089, e-ISSN 2651-5869

https://journal.uniku.ac.id/index.php/quagga

Widanti Fitri N, Budi Murtiyasa dan Ariyanto. 2012. Upaya Meningkakan Kemampuan Penalaran Matematis Siswa Melalui Model Pembelajaran CORE (Connecting, Organizing, Reflecting, Extending). [Online]. Jurnal Matematika. Tersedia: eprints.ums.ac.id/19613/9/2_Naskah_Pu blikasi_CORE.pdf. Diakses pada tanggal 19 Mei 2016 